\title{
PERBEDAAN KETERAMPILAN BELAJAR ANTARA SISWA IPA DAN IPS
}

\author{
Isnaria Rizki Hayati ${ }^{1}$, Eko Sujadi ${ }^{2}$ \\ ${ }^{1}$ Universitas Islam Negeri (UIN) Suska Riau \\ ${ }^{2}$ Institut Agama Islam Negeri (LAIN) Kerinci \\ email: isnariarizkihayati@gmail.com, ekosujadi91@gmail.com
}

\begin{abstract}
Learning skills is a skill that has been mastered by students to be successful in learning on college by mastering the material that have been learned. The purpose of this study are to describes: 1) the learning skills of the tenth grade students in MAN 1 Pekanbaru ?; 2) learning skills students of class X Social in MAN 1 Pekanbaru; and 3) differences in learning skills between students of class X science and class X Social in MAN 1 Pekanbaru ?. This research was used a quantitative approach with comparative methods. The instrument was used a questionnaire for learning skills. Besides, questionnaire on learning skills was adapted from the item AUM statement PTSDL Format-2 for high school related to learning skills which then the statement of each items was corrected. Then, data were analyzed using descriptive techniques and t-tests. Furthermore, the result of this study included that: 1) the learning skills of students in Sciences class are in the medium category of $71.58 \%$; 2) the learning skills of students in social class are in the medium category which is $69.12 \%$; and 3) there are significant differences in learning skills between science and social students of MAN 1 Pekanbaru.
\end{abstract}

Keyword: Learning Skills, Science Students, Social Science Students 


\section{PENDAHULUAN}

Pendidikan akan mendorong manusia untuk belajar aktif, mandiri, dan memberdayakan semua potensi yang ada di dalam diri individu. Salah satu cara yang dapat dilakukan adalah dengan belajar. Pada hakikatnya belajar adalah salah satu bentuk tingkah laku peserta didik dalam usaha mengembangkan potensi dan usaha untuk mencapai tujuan. Selain itu, belajar harus disertai dengan keinginan dan kemauan yang kuat dari siswa untuk mencapai tujuan. Dalyono (1997: 49) mengemukakan bahwa belajar adalah suatu usaha, perbuatan yang dilakukan secara sungguh-sungguh, dengan sistematis, mendayagunakan semua potensi yang dimiliki. Belajar merupakan kegiatan yang mempunyai tujuan dan membutuhkan cara atau prosedur yang efektif untuk meraih kesuksesan belajar. Belajar menurut Sardiman (2007:21) adalah usaha untuk mengubah tingkah laku. Selanjutnya, dalam perspektif islam, belajar merupakan kewajiban bagi setiap muslim dalam rangka memperoleh ilmu pengetahuan sehingga derajat kehidupannya meningkat, sesuai dengan firman Allah SWT dalam Q.S. AlMujadilah (56) : 11:

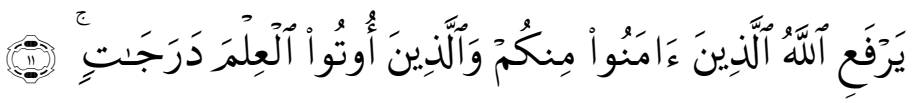

Artinya : "Allah akan meninggikan orang-orang yang beriman di antaramu dan orang-orang yang diberi ilmu pengetabuan beberapa derajat”.

Perubahan tersebut tidak hanya berkaitan dengan penambahan ilmu pengetahuan, tetapi juga berbentuk kecakapan, keterampilan, sikap, pengertian, harga diri, minat, watak dan penyesuaian diri. Dalam rangka mencapai tujuan tersebut, sekolah merupakan salah satu wadah yang bertanggungjawab untuk mengembangkan semua potensi, kreativitas, keterampilan-keterampilan yang ada pada diri siswa. Namun, hal yang terjadi kebanyakan siswa kurang mengetahui cara belajar yang baik. Pihak sekolah lebih menekankan siswa untuk menguasai isi materi pelajaran yang diajarkan guru. Hal tersebut juga masih terjadi disekolah tempat penelitian ini di MAN 1 Pekanbaru. Sekolah tersebut masih menekankan siswa untuk lebih menguasai isi materi tanpa memerhatikan apakah siswa tersebut mampu atau tidaknya dalam proses pembelajaran.

Padahal orientasi belajar bukan hanya penguasaan terhadap materi yang dipelajari, tetapi menekankan pada pemahaman terhadap proses serta keterampilan yang diperlukan untuk menguasai suatu materi. Penguasaan terhadap cara-cara belajar yang baik sebetulnya memberikan gambaran tentang kadar penguasaan siswa terhadap keterampilan belajar, karena dengan menguasai keterampilan belajar, siswa akan menyadari bagaimana cara belajar yang 
terbaik sehingga menjadi lebih bertanggungjawab terhadap cara belajarnya. Oleh karena keterampilan belajar adalah keterampilan yang diperoleh setelah melalui pendidikan dan latihan dan diiringi dengan kesabaran, keuletan dan ketekunan. Sebagaimana didalam QS. AlMulk (29):2 mengungkapkan bahwa manusia yang baik adalah manusia yang paling terampil dalam pekerjaannya:

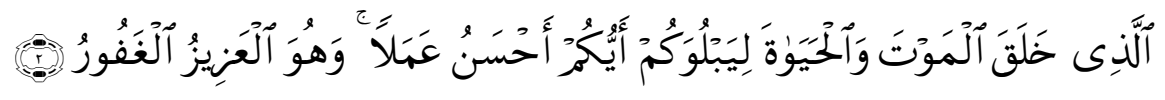

Artinya : Yang menjadikan mati dan bidup, supaya Dia menguji kamu, siapa di antara kamu yang lebih baik amalnya. dan Dia Maha Perkasa lagi Maha Pengampun”.

Sehingga keterampilan dalam pendidikan pada prinsipnya adalah pendidikan yang melibatkan semua potensi yang ada pada jasmani dan rohani. Dari segi jasad, karakteristik manusia memiliki dorongan untuk berkembang, mempertahankan diri dan berketurunan. Penguasaan siswa terhadap keterampilan belajar dapat meminimalkan hambatan belajar siswa. Cara belajar yang baik sebagai upaya memfasilitasi siswa dalam memecahkan masalah terhadap belajarnya dapat dimanipulasi. Artinya dapat dibuat, dirintis, serta diciptakan sesuai dengan apa yang siswa butuhkan, terutama bagaimana mengembangkan keterampilan belajarnya sebagai aset dalam meningkatkan kualitas belajar yang dimiliki siswa.

Salah satu karakteristik potensi peserta didik yang perlu diperhatikan guru yaitu adanya perbedaaan individu dalam hal keterampilan belajar. Adanya masalah perbedaan individu dalam belajar kadangkala sukar diamati, karena masalah itu tidak pernah menampakkan dirinya, seperti ada siswa diperhatikan dan diamati guru tidak punya masalah, tetapi siswa itu mengalami masalah yang cukup berat.

Di sekolah keterampilan-keterampilan itu ada yang diperoleh melalui proses belajar mengajar yang diberikan oleh guru mata pelajaran tertentu, dan ada pula yang diperoleh siswa melalui guru bimbingan dan konseling yang disebut layanan bimbingan dan konseling (BK). Secara formal layanan bimbingan dan konseling adalah salah satu komponen yang bertanggung jawab untuk melayani siswa dalam mengembangkan keterampilan-keterampilan tersebut di sekolah. Selain itu, juga sebagai muara akhir dari keberhasilan program pendidikan pada umumnya dan program bimbingan dan konseling pada khususnya adalah pada saat siswa berhasil dalam bidang akademik yang ditunjukkan dengan dikuasainya keterampilan belajar sehingga siswa mampu mengembangkan diri dan merencanakan masa depan serta memiliki keterampilan yang bagus dalam belajarnya. 
Sejalan dengan itu,guru bimbingan dan konseling juga berperan dalam hal ini yaitu sebagai pendidik untuk berpartisipasi aktif mengarahkan dan mengembangkan potensi peserta didik, guru bimbingan dan konseling/konselor sekolah memberikan layanan berupa bimbingan dan konseling bagi setiap siswa, sebagaimana tertuang dalam Peraturan Menteri Pendidikan Nasional No. 35 Tahun 2010 tentang Petunjuk Teknis Ketentuan Pelaksanaan Jabatan Fungsional dan Angka Kreditnya, "Bimbingan dan konseling adalah pelayanan bantuan untuk peserta didik secara perseorangan maupun kelompok agar mampu mandiri dan berkembang secara optimal dalam bidang bimbingan pribadi, bimbingan belajar, bimbingan sosial, bimbingan karir melalui berbagai jenis layanan dan kegiatan pendukung berdasarkan norma yang berlaku".

Berdasarkan hal di atas tampaklah bahwa tugas utama seorang guru bimbingan dan konseling/konselor ialah memberikan bantuan pelayanan melalui bimbingan kearah kemandirian peserta didik, baik bimbingan yang menyangkut dengan keadaan pribadi sampai kepada bimbingan yang menyangkut kepada lingkungan sosial dan belajar yang berada di sekitar peserta didik. Dengan adanya pelayanan bimbingan dan konseling berarti guru bimbingan dan konseling telah membantu peserta didik untuk mengembangkan potensinya secara optimal. Secara khusus bimbingan dan konseling bertujuan untuk membantu siswa agar dapat mencapai tugas-tugas perkembangannya yang meliputi aspek pribadi, sosial, belajar, dan karir. Melalui pelayanan bimbingan dan konseling diharapkan siswa mampu mengatasi permasalahan yang dialaminya, seperti yang diungkapkan oleh BSNP (2006) sebagai berikut, "Pelayanan bimbingan dan konseling memfasilitasi pengembangan peserta didik secara individual, kelompok, dan atau klasikal, sesuai dengan kebutuhan, potensi, bakat, minat, perkembangan, kondisi serta peluang-peluang yang dimiliki serta membantu peserta didik mengatasi kelemahan dan hambatan maupun masalah".

Hal ini mengandung makna bahwa guru pembimbing hendaknya mengerti dan memahami siswa, baik itu bakat, minat, potensi, kreativitas, keterampilan yang dimiliki, maupun perkembangannya. Apabila guru bimbingan dan konseling sudah mengerti dan memahami secara baik, maka hal tersebut akan memberikan peluang bagi guru pembimbing untuk membantu peserta didik mengatasi kelemahan, hambatan, serta masalah yang dialaminya dalam bidang pribadi, sosial, belajar dan karir. Selain itu, guru bimbingan dan konseling diharapkan mampu membimbing peserta didik untuk menjalankan perannya sebagai siswa yaitu belajar salah satunya dalam hal keterampilan belajar.

Berdasarkan fenomena yang peneliti temukan di MAN 1 Kota Pekanbaru, ditemukan beberapa permasalahan, di antaranya: 1) kebanyakan siswa baik jurusan IPA dan IPS kurang 
mengetahui cara belajar yang baik. Pihak sekolah lebih menekankan siswa untuk menguasai isi materi pelajaran yang diajarkan guru; 2) siswa memerlukan waktu tambahan untuk menyelesaikan tugasnya; 3) mudah lupa materi pelajaran yang diajarkan; 4) siswa sulit meringkas materi pelajaran yang dibaca; dan 5) ada sebagian siswa baik IPA maupun IPS kurang berminat dan cepat bosan membaca buku pelajaran.

Untuk mengantisipasi hal di atas dalam rangka mengembangkan potensi diri agar mencapai hasil yang maksimal, individu perlu memiliki keterampilan belajar yang bagus sehingga memperoleh prestasi yang diinginkan baik pada siswa jurusan IPA maupun siswa jurusan IPS.

Sesuai dengan latar belakang tersebut di atas maka penulis tertarik melakukan penelitian dengan judul: Perbedaan antara Keterampilan Belajar Siswa Jurusan IPA dan IPS serta Implikasinya dalam Program Bimbingan Konseling di MAN 1 Kota Pekanbaru. Adapun rumusan masalah dalam penelitian ini antara lain: 1) bagaimanakah keterampilan belajar siswa kelas X IPA di MAN 1 Pekanbaru?; 2) bagaimanakah keterampilan belajar siswa kelas X IPS di MAN 1 Pekanbaru; dan 3) apakah terdapat perbedaan keterampilan belajar antara siswa kelas X IPA dan keterampilan belajar siswa kelas X IPS di MAN 1 Pekanbaru?

\section{METODOLOGI}

Penelitian ini menggunakan pendekatan kuantitatif dengan metode komparatif. Menurut Sugiyono (2006) metode komparatif bertujuan untuk membandingkan keberadaan suatu variabel atau lebih pada dua atau lebih sampel yang berbeda, atau pada waktu yang berbeda. Metode komparatif digunakan untuk mengetahui perbedaan keterampilan belajar siswa kelas X IPA dan IPS di MAN 1 Pekanbaru. Adapun populasi pada penelitian ini adalah seluruh siswa jurusan IPA dan IPS kelas X MA Negeri 1 Pekanbaru, IPA berjumlah 161 siswa dan IPS berjumlah 115 siswa. Untuk menentukan sampel menggunakan teknik proportional random sampling (sampling acak yang beraturan). Berdasarkan rumus Slovin diperoleh jumlah sampel (n) sebanyak 163 siswa. Penulis membuat pertanyaan secara tertulis yang diajukan dan disebarkan kepada sampel yakni sebanyak 163 orang siswa. Angket berisi indikator-indikator pada objek penelitian yang telah ditentukan. Angket yang digunakan adalah angket tertutup dan digunakan untuk mendapatkan data tentang Perbedaan keterampilan belajar siswa IPA dan IPS. Item- item pernyataan angket keterampilan belajar diadaptasi dari item pernyataan AUM PTSDL Format- 2 SLTA berkaitan dengan keterampilan belajar yang kemudian item pernyataan tersebut diperbaiki kalimatnya. Selanjutnya angket tersebut dilakukan uji validitasi dan reliabilitas instrumen. Untuk menguji signifikansi perbedaan dua buah mean yang berasal 
dari dua buah distribusi adalah dengan menggunakan teknik t test (Suharsimi Arikunto, 2006), dalam hal ini untuk mengetahui perbedaan keterampilan belajar siswa jurusan IPA dan IPS.

\section{TEMUAN}

\section{Hasil Penelitian}

Berdasarkan verifikasi terhadap data penelitian, seluruh data yang diperoleh dari hasil pengadministrasian terhadap siswa layak diolah yaitu sebanyak 163 data. Berikut dikemukakan deskripsi data hasil penelitian.

Tabel Distribusi Frekuensi dan Persentase Keterampilan Belajar Siswa Jurusan IPA

\begin{tabular}{lccc}
\hline & Kategori & Frekuensi $(\mathrm{f})$ & Persentase $(\%)$ \\
\hline Tinggi & 20 & $21,05 \%$ \\
Sedang & 68 & $71,58 \%$ \\
Rendah & 7 & $7,37 \%$ \\
\hline \multicolumn{2}{c}{ Jumlah } & 95 orang & $100 \%$ \\
\hline
\end{tabular}

Dari tabel di atas dapat dilihat gambaran tentang keterampilan belajar siswa jurusan IPA kelas X di MAN 1 Pekanbaru yang secara umum tergolong sedang, yakni sebanyak 68 orang atau sebesar 71,58\%, pada kategori tinggi sebanyak 20 orang atau sebesar 21,05\%, dan pada kategori rendah sebanyak 7 orang atau sebesar 7,369\%.

Tabel Distribusi Frekuensi dan Persentase Keterampilan Belajar Siswa Jurusan IPS

\begin{tabular}{|c|c|c|}
\hline Kategori & Frekuensi (f) & Persentase $(\%)$ \\
\hline Tinggi & 11 & $16,18 \%$ \\
\hline Sedang & 47 & $69,12 \%$ \\
\hline Rendah & 10 & $14,70 \%$ \\
\hline Jumlah & 68 orang & $100 \%$ \\
\hline
\end{tabular}

Dari tabel di atas dapat dilihat gambaran tentang keterampilan belajar siswa jurusan IPS kelas X di MAN 1 Pekanbaru yang secara umum tergolong sedang, yakni sebanyak 47 orang atau sebesar $69,12 \%$, pada kategori tinggi sebanyak 11 orang atau sebesar 16,18\%, dan pada kategori rendah sebanyak 10 orang atau sebesar 14,70.

Untuk mengetahui perbedaan keterampilan belajar antara siswa jurusan IPA dan IPS maka digunakan rumus Ttest. Adapun hasil perhitungannya dapat dilihat pada tabel berikut: Tabel Perbedaan Keterampilan Belajar Siswa Jurusan IPA dan IPS

\begin{tabular}{lccc}
\hline & thitung & $t_{\text {tabel }}$ & df \\
\hline Perbedaan keterampilan belajar siswa jurusan & 7,149 & 1.980 & 161 \\
IPA dan IPS & & & \\
\hline
\end{tabular}


Berdasarkan tabel di atas dapat dilihat bahwa $t_{\text {hitung }}$ antara keterampulan belajar siswa jurusan IPA dan IPS sebesar 7.149, sedangkan $t_{\text {tabel }}$ sebesar 1.980 pada taraf signifikan $5 \%$. Berdasarkan analisis tersebut diketahui bahwa 7,149>1,980 dengan demikian dapat disimpulkan bahwa terdapat perbedaan keterampilan belajar antara siswa jurusan IPA dan IPS.

\section{Pembahasan}

Keterampilan merupakan kecakapan melakukan suatu tugas tertentu yang diperoleh dengan cara berlatih terus menerus, karena keterampilan tidak datang sendiri secara otomatis melainkan secara sengaja diprogramkan melalui latihan terus menerus. Jika dikaitkan dengan makna belajar di atas, keterampilan belajar adalah keahlian yang didapatkan (acquired skill) oleh seorang individu melalui proses latihan yang kontinyu dan mencakup aspek optimalisasi caracara belajar baik dalam domain kognitif, afektif ataupun psikomotor (Budiarjo, 2007: 11).

Menjalani proses belajar merupakan bagian yang amat penting dalam kegiatan belajar di sekolah. Melalui kegiatan belajar materi pokok yang harus dikuasai siswa akan dibahas oleh guru bersama siswa, melatihkan bermacam-macam keterampilan, mengerjakan berbagai tugas sehingga siswa melakukan kegiatan belajar dalam rangka memahami dan menguasai materi pokok yang dimaksudkan. Menurut Budiarjo (2007:28) keterampilan merupakan kegiatankegiatan yang bersifat neoromuscular, artinya menuntut kesadaran yang tinggi. Melalui keterampilan belajar, seseorang memiliki kemampuan menetapkan langkah-langkah yang akan ia lalui sewaktu memasuki aktivitas belajar. Misalnya, sewaktu akan menghafal sebuah definisi, seseorang tahu langkah pertama yang harus dilakukan sebelum menghafal.

Dibandingkan dengan kebiasaan, keterampilan merupakan kegiatan yang lebih membutuhkan perhatian serta kemampuan intelektual, selalu berubah dan sangat disadari oleh individu. Dalam proses menjadi (on becoming process), dimana siswa memerlukan empat pilar yakni pengetahuan, keterampilan, kemandirian dan kemampuan untuk menyesuaikan diri dan bekerjasama.

Nirwana, et al (2006) keterampilan belajar adalah suatu keterampilan yang sudah dikuasai oleh siswa untuk dapat sukses dalam menjalani pembelajaran di kampus (sukses akademik) dengan menguasai materi yang dipelajari. Dengan kata lain, keterampilan belajar merupakan suatu keahlian tertentu yang dimiliki oleh siswa, jika keahlian tersebut dilatihkan terus-menerus akan menjadi suatu kebiasaan yang baik bagi siswa dalam belajar.

Berdasarkan pengujian hipotesis diketahui bahwa terdapat perbedaan yang signifikan keterampilan belajar antara siswa IPA dan IPS. Temuan penelitian ini mendukung penelitianpenelitian terdahulu. Agnes Dwijayanti Ningrum (2012) melalui penelitiannya mengungkapkan 
bahwa terdapat perbedaan motivasi belajar antara siswa Jurusan IPA dan IPS. Begitu halnya dengan penelitian yang dilakukan Oktofian (2014) bahwa terdapat perbedaan motivasi belajar antara siswa IPA dan IPS di SMA N 1 Muaro Jambi. Sisca Folastri (2012) juga melakukan uji beda terhadap keterampilan belajar siswa berprestasi tinggi dan rendah, bahwa siswa dengan prestasi belajar yang tinggi lebih baik dalam hal keterampilan belajarnya.

Selain mengenai keterampilan belajar, beberapa objek kajian juga menjadi fokus peneliti-peneliti terdahulu. Oktavya One Krisnawati (2011) melakukan kajian tingkat stres antara siswa IPA dan IPS, bahwa tingkat stress siswa IPA lebih tinggi dibandingkan siswa IPS. Imam Purkana (2014) juga mengungkapkan bahwa terdapat perbedaan yang signifikan antara siswa IPA dan IPS dalam memahami materi pembelajaran. Rahmi Dwi Febriani, A. Muri Yusuf \& Mega Iswari (2016) melakukan uji beda aspirasi karir antara siswa IPA dan IPS. Walauapun secara umum tidak ditemukan perbedaan yang signifikan melalui serangkaian tes secara statistic, namun aspirasi karir siswa IPS lebih tinggi dibandingkan siswa IPA.

Mengingat pentingnya memiliki keterampilan belajar, oleh sebab itu siswa jurusan IPA dan IPS hendaknya selalu berusaha untuk memperbaiki serta meningkatkan keterampilan belajar sehingga berada pada pada kategori baik dan baik sekali dengan cara berusaha mempelajari dan melatihkan keterampilan belajar, baik belajar sendiri maupun belajar dalam kelompok, berusaha untuk memiliki berbagai keterampilan dalam belajar, menyiapkan diri dalam belajar dengan selalu menumbuhkan semangat belajar dan selalu memperhatikan kondisi kesehatan serta berusaha secara positif untuk memiliki respon emosional yang tepat dalam setiap situasi yang dihadapi. Guru BK juga harus selalu meningkatkan dan mengembangkan layanan bimbingan dan konseling dalam bidang keterampilan belajar, seperti memberikan layanan informasi, layanan penguasaan konten dan layanan bimbingan kelompok yang terkait dengan keterampilan belajar seperti keterampilan mencatat pelajaran, keterampilan bertanya, keterampilan mengikuti pelajaran, keterampilan membaca, keterampilan konsentrasi dalam belajar serta keterampilan penyelesaian tugas. Diharapkan juga guru BK mengadakan pelatihan tentang keterampilan belajar secara terprogram sehingga siswa diharapkan benarbenar memahami dan terampil dalam belajar. Dengan program yang tepat, selain keterampilan belajar yang meningkat, karakteristik kepribadian seperti teliti, cermat, peduli, memiliki usaha yang baik, tidak akan cepat menyerah dan tidak pasrah terhadap keadaan ketika memiliki tujuan-tujuan tertentu juga akan turut berkembang (Sujadi, Eko., Meditamar, Muhd Odha., \& Ahmad, Bukhari, 2018). 


\section{PENUTUP}

Dari hasil penelitian dan pembahasan yang telah dikemukakan pada halaman-halaman sebelumnya maka dapat diambil kesimpulan sebagai berikut:

1. Keterampilan belajar siswa jurusan IPA berada dalam kategori sedang yakni sebesar $71,58 \%$.

2. Keterampilan belajar siswa jurusan IPS berada dalam kategori sedang yakni sebesar $69,12 \%$.

3. Terdapat perbedaan yang signifikan antara keterampilan belajar siswa jurusan IPA dan IPS di MAN 1 Pekanbaru yaitu sebesar 7.149.

\section{REFERENSI}

BSNP. (2006). Panduan Pengembangan Diri. Jakarta: Pusat Kurikulum BSNP.

Budiarjo, Lily. (2007). Keterampilan Belajar. Yogyakarta: Penerbit Andi.

Dalyono. M. (1997). Psikologi Pendidikan. Jakarta: Rineka Cipta.

Imam Purkana. (2014). Perbandingan Kemampuan Kognitif Dalam Pemahaman Pembelajaran Penjasorkes Antara Siswa IPA Dan siswa IPS Kelas X Di SMA Negeri 1 Peukan Bada Aceh Besar. Penjaskesrek, Vol. 1, No.1: 1-16.

Ningrum, Agnes Dwijayanti. (2012). Perbedaan motivasi belajar siswa program IPA dan IPS kelas XI SMA BOPKRI 2 Yogyakarta tahun ajaran 2010/2011 dan implikasinya terhadap usulan topik-topik bimbingan. Skripsi tidak diterbitkan. Yogkayarta: Sanata Dharma University

Nirwana, Herman, Zuwirna, Hasanuddin, Yuskal Kusman, Neviyarni. (2006). Belajar dan Pembelajaan. Padang: FIP UNP.

Oktavya One Krisnawati. (2011). Perbedaan Tingkat Kecemasan Siswa Kelas XI Antara Jurusan IPA dan IPS di SMA Negeri 1 Babadan Ponorogo. Skripsi tidak diterbitkan. Surakarta: Universitas Muhammadiyah Surakarta.

Oktofian, Reza Dwi. (2014). Perbedaan Motivasi Belajar Antara Siswa IPA dan IPS Di SMA N 1 Muaro Jambi. Skripsi tidak diterbitkan. Jambi: FKIP Universitas Jambi..

Rahmi Dwi Febriani, A. Muri Yusuf \& Mega Iswari. (2016). Perbedaan Aspirasi Karier Siswa ditinjau dari Jenis Kelamin, Jurusan, dan Tingkat Pendidikan Orangtua serta Implikasinya terhadap Pelayanan Bimbingan dan Konseling. Konselor, Vol. 5, No. 3: 160-168.

Sardiman A. M. (2007). Interaksi dan Motivasi Belajar-mengajar. Jakarta: Raja Grafindo.

Sisca Folastri. (2012). Perbedaan Keterampilan Belajar Siswa Berprestasi Tinggi dan Berprestasi Rendah di SMA Negeri Kota Padang serta Implikasinya dalam Bimbingan dan Konseling. Tesis tidak diterbitkan. Program Studi Bimbingan dan Konseling Program Pascasarjana Fakultas Ilmu Pendidikan Universitas Negeri Padang. 
Sujadi, Eko., Meditamar, Muhd Odha., Ahmad, Bukhari. (2018). Pengaruh Konsep Diri Dan Locus of Control Terhadap Motivasi Berprestasi. Educational Guidance and Counseling Development Journal, 1 (1), 1-18.

Sugiyono. (2006). Metode Penelitian Pendidikan: Pendekatan Kuantitatif, Kualitatif dan R\&D. Bandung: Alfabeta. 